\title{
Hypertriglyceridemia and Cholesteryl Ester Transfer Protein Interact to Dramatically Alter High Density Lipoprotein Levels, Particle Sizes, and Metabolism Studies in Transgenic Mice
}

Tony Hayek, ${ }^{\star}$ Neal Azrolan, ${ }^{\star}$ Roy B. Verdery, ${ }^{\star}$ Annemarie Walsh, ${ }^{*}$ Tova Chajek-Shaul,* Luis B. Agellon," Alan R. Tall," and Jan L. Breslow*

${ }^{*}$ Laboratory of Biochemical Genetics and Metabolism, The Rockefeller University, New York 10021-6399; ${ }^{\ddagger}$ Arizona Center on Aging, Tucson, Arizona 85719; and ${ }^{\S}$ Department of Medicine, Columbia College of Physicians and Surgeons, New York 10032

\section{Abstract}

Several types of transgenic mice were used to study the influence of hypertriglyceridemia and cholesteryl ester transfer protein (CETP) expression on high density lipoprotein (HDL) levels, particle sizes, and metabolism. The presence of the CETP transgene in hypertriglyceridemic human apo CIII transgenic mice lowered HDL-cholesterol (HDL-C) 48\% and apolipoprotein (apo) A-I 40\%, decreased HDL size (particle diameter from 9.8 to $8.8 \mathrm{~nm}$ ), increased HDL cholesterol ester (CE) fractional catabolic rate (FCR) $65 \%$ with a small decrease in HDL CE transport rate (TR) and increased apo A-I FCR 15\% and decreased apo A-I TR 29\%. The presence of the CETP transgene in hypertriglyceridemic mice with human-like HDL, human apo A-I apo CIII transgenic mice, lowered HDL-C $61 \%$ and apo A-I 45\%, caused a dramatic diminution of HDL particle size (particle diameters from 10.3 and 9.1 to $7.6 \mathrm{~nm}$ ), increased HDL CE FCR by $107 \%$ without affecting HDL CE TR, and increased apo A-I FCR 35\% and decreased apo A-I TR 48\%. Moreover, unexpectedly, hypertriglyceridemia alone in the absence of CETP was also found to cause lower HDL-C and apo A-I levels primarily by decreasing TRs. Decreased apo A-I TR was confirmed by an in vivo labeling study and found to be associated with a decrease in intestinal but not hepatic apo A-I mRNA levels. In summary, the introduction of the human apo A-I, apo CIII, and CETP genes into transgenic mice produced a high-triglyceride, low-HDL-C lipoprotein phenotype. Human apo A-I gene overexpression caused a diminution of mouse apo A-I and a change from monodisperse to polydisperse HDL. Human apo CIII gene overexpression caused hypertriglyceridemia with a significant decrease in HDL-C and apo A-I levels primarily due to decreased HDL CE and apo A-I TR but without a profound change in HDL size. In the hypertriglyceridemic mice, human CETP gene expression further reduced HDL-C and apo A-I levels, primarily by increasing HDL CE and apo A-I FCR, while dramatically reducing HDL size. This study provides insights into the genes that may cause the high-triglyceride, low-HDL-C phenotype in humans and the metabolic mechanisms involved. (J. Clin. Invest. 1993. 92:1143-1152.)

Address reprint requests to Dr. Jan L. Breslow, Box H-32, The Rockefeller University, 1230 York Avenue, New York, NY 10021-6399.

Received for publication 1 October 1992 and in revised form 15 March 1993.

J. Clin. Invest.

(C) The American Society for Clinical Investigation, Inc.

0021-9738/93/09/1143/10 \$2.00

Volume 92, September 1993, 1143-1152
Key words: cholesteryl ester transfer protein • high density lipoprotein - hypertriglyceridemia - metabolism - particle size distribution

\section{Introduction}

In humans there is a strong association between hypertriglyceridemia and low levels of HDL cholesterol (HDL-C) ${ }^{1}$ and apo A-I, the principal HDL apolipoprotein (1-10). Hypertriglyceridemia is also associated with a greater reduction of HDL-C than apo A-I as well as with decreased HDL particle size (11). It has been proposed that these associations are due to increased exchange of core triglycerides in VLDL for core cholesteryl esters in HDL mediated by the cholesteryl ester transfer protein (CETP) driven by elevated plasma concentrations of triglyceride-rich lipoproteins. Triglycerides in HDL are then hydrolyzed by hepatic lipase with diminution of HDL size, which has been associated with increased fractional catabolic rate (FCR) of apo A-I, perhaps due to increased filtration by the kidney (12). The evidence for this proposal is based largely on in vitro studies (2-4) and limited in vivo studies (13), which are largely correlative. Now, through transgenic technology, it is possible to examine the specific effects of hypertriglyceridemia and CETP on HDL-C and apo A-I levels and metabolism and on HDL size.

Control mice have low triglyceride levels, lack CETP activity in their plasma, and tend to have a single-size distribution of HDL particles. Through the introduction of human lipoprotein transport protein genes, we have been able to make transgenic mice that are a better model for the study of the hypertriglyceridemia-low-HDL-C relationship. Through the introduction of the human apo CIII gene a hypertriglyceridemic mouse model has been created (14). These animals accumulate apparently normal VLDL in plasma with the primary metabolic defect in VLDL fractional catabolic rate (15). Through the introduction of the human CETP gene, mice have been created with human-like levels of CETP mass and activity in plasma (16). These animals showed a modest reduction of HDL-C and very slight reduction of apo A-I levels in their plasma. Finally, by introducing the human apo A-I gene, mice were created with increased levels of HDL-C (17). In these mice, mouse apo A-I was suppressed and the HDL which contained mostly human apo A-I had several major size distributions of HDL particles comparable to human $\mathrm{HDL}_{2 b}$ and $\mathrm{HDL}_{3 a}(18,19)$. In a recent

1. Abbreviations used in this paper: $\mathrm{CE}$, cholesterol ester, CETP, cholesteryl ester transfer protein; FCR, fractional catabolic rate; HDL-C, HDL cholesterol; TR, transport rate. 
study we crossed the HuAITg and HuCETPTg mice and showed on the background of human apo A-I that CETP induced a greater reduction of HDL-C and apo A-I levels and HDL particle size (20). In the plasma of these HuAICETPTg mice there was also a stronger HDL-CETP interaction.

In the current study we have crossbred mice with these transgenes to examine the effect of hypertriglyceridemia with or without CETP on the background of mouse or human apo A-I on HDL-C levels, HDL particle sizes, and HDL CE and apo A-I metabolism. We have found that hypertriglyceridemia in the presence of CETP has a profound effect on HDL, but that there is also a previously unsuspected effect in the absence of CETP. These studies help clarify the roles of molecules which may mediate the development of a common atherogenic lipoprotein phenotype in humans.

\section{Methods}

Transgenic mice. Transgenic mice were created as previously described (14-17). The fertilized eggs injected with foreign DNA were F1 $(\mathrm{C} 57 \mathrm{~B} 1 / 6 \mathrm{~J} \times \mathrm{CBA} / \mathrm{J})$. Transgenic mice were confirmed by tail tip DNA analysis and mated to F1's of the same genetic background. Comparisons in metabolic studies were with nontransgenic litter mates. Four lines of human apo CIII transgenic (HuCIIITg) mice were used $(2674,3641,3707,2721)$. Two of these lines were previously described (2674 and 2721)(14) and the other two were made with the same DNA construction. In these lines the apo CIII transgene was expressing primarily in the liver (> 90\%) with some intestinal expression (14). These lines had different mean triglyceride levels which were directly proportional to human apo CIII gene expression (14). One line of human CETP transgenic (HuCETPTg) mice was used which has been previously described (16). This line was made with a DNA construction which contains a CETP minigene driven by the mouse metallothionein I (MMTH I) gene promoter. One line of human apo A-I transgenic (HuAITg) mice (179), which was previously described (17), was used. Finally, two lines of transgenic mice $(4867,4868)$ were used which contained both the human apo A-I and apo CIII genes (21). In these lines the apo A-I transgene was expressed equally in liver and intestine, with the apo CIII transgene expressed primarily in liver $(>90 \%)$ with some intestinal expression. These genes are adjacent to each other on the genome and convergently transcribed. The piece of DNA used extended from $0.3 \mathrm{~kb} 5^{\prime}$ to the apo A-I gene to $1.4 \mathrm{~kb} 5^{\prime}$ to the apo CIII gene. The HuCIIICETPTg mice were generated by crossing HuCIIITg mouse line 3707 with HuCETPTg mice. The HuAICIIICETPTg mice were generated by crossing the HuAICIIITg mouse lines $(4867,4868)$ with HuCETPTg mice. The HuAICIIITg line was used rather than HuAITg and HuCIIITg lines to minimize the number of crosses required to get animals expressing all three human transgenes. The transgenic lines have been carefully studied for drift of the phenotype with time and none has been observed. In addition, the animals were studied between 10 and $20 \mathrm{wk}$ of age, during which time in a given mouse there are no significant temporal effects on the lipoprotein phenotype (22).

Blood sampling protocol. Animals were placed in metabolic cages in animal rooms with alternating 12 -h periods of light (7 a.m. to 7 p.m.) and dark (7 p.m. to 7 a.m.) with ad lib access to food and water. Mice $12-16$ wk old (20-30 $\mathrm{g}$ in weight) were given a regular mouse laboratory diet (Purina Chow 5001; Ralston Purina Co., St. Louis, MO) and distilled water for $7 \mathrm{~d}$, and then a Chow diet and water, supplemented with $25 \mathrm{mM} \mathrm{ZnSO}_{4}$ for $7 \mathrm{~d}$ to raise the level of plasma CETP. At the end of each 7-d period, the mice were fasted overnight and blood was collected the following morning from the retroorbital plexus under methoxyflurane anesthesia.

Plasma lipid and lipoprotein analysis. Triglyceride and total cholesterol were determined enzymatically using the Boehringer Mannheim (Indianapolis, IN) reagents (nos. 126012 and 236691, respectively).
HDL and other lipoprotein fractions were separated by ultracentrifugation in an Airfuge (Beckman, Instruments, Inc., Fullerton, CA) as previously described (17). In the HDL fraction, free cholesterol and total cholesterol (after saponification) were measured by gas chromatography with coprostanol as an internal standard. The cholesterol ester (CE) was taken as the difference between the two.

Nondenaturing gradient gel electrophoresis. HDL particle size distribution was evaluated as previously described (23, 24). Plasma specimens from control, HuCIIITg, HuCIIICETPTg, HuAITg, HuAICIIIT, and HuAICIIICETPTg mice were subjected to gradient gel electrophoresis. In a $175-\mu \mathrm{l}$ airfuge tube, $40 \mu \mathrm{l}$ of plasma was adjusted to $d 1.21 \mathrm{~g} / \mathrm{ml}$ with $1.35 \mathrm{~g} / \mathrm{ml} \mathrm{KBr}$ and $1 \mathrm{mM}$ EDTA. This mixture/solution was then ultracentrifuged at $100,000 \mathrm{~g}$ for $5 \mathrm{~h}$ (Airfuge). $30 \mu \mathrm{l}$ was then aspirated from the top of the tube, electrophoresed for $20 \mathrm{~min}$ at $70 \mathrm{~V}$ and then for $18-24 \mathrm{~h}$ at $125 \mathrm{~V}$ on nondenaturing 4-30\% polyacrylamide gradient gels (PAA 4/30, Pharmacia LKB, Piscataway, NJ). Gels were simultaneously stained and fixed in $0.05 \%$ Coomassie Blue R-250 (Bio-Rad Laboratories, Richmond, CA), 9\% acetic acid, and $20 \%$ methanol, then destained with two changes of $9 \%$ acetic acid $20 \%$ methanol followed by $9 \%$ acetic acid. Stained gels were scanned using a digital scanning densitometer (model 620, Bio Rad Laboratories) equipped with a $600-\mathrm{nm}$ interference filter, and the data were entered into a personal computer. Scans were analyzed by Gaussian modeling as described previously (24). Stokes' radius of HDL particles was estimated by comparing migration distances with those of thyroglobulin $(8.50 \mathrm{~nm})$, apoferritin $(6.10 \mathrm{~nm})$, catalase $(5.20 \mathrm{~nm})$, lactate dehydrogenase $(4.08 \mathrm{~nm})$, and bovine serum albumin $(3.55 \mathrm{~nm})$.

Fast protein liquid chromatography (FPLC) analysis of lipoproteins. Aliquots $(200 \mu \mathrm{l})$ of plasma from the HuCIIITg, HuCIIICETPTg, HuAICIIITg, and HuAICIIICETPTg mice were loaded into a 500- $\mu \mathrm{l}$ teflon sample loop for application to two Superose 6 columns (HR 10/30) connected in series (FPLC system, Pharmacia) (25). Lipoproteins were eluted at $0.3 \mathrm{ml} / \mathrm{min}$ with $1 \mathrm{mM}$ EDTA, $154 \mathrm{mM} \mathrm{NaCl}$. After the initial $12 \mathrm{ml}$ had eluted, 50 fractions $(0.5 \mathrm{ml})$ were collected. $60 \mathrm{ml}$ of buffer was passed through the columns between sample loading. Cholesterol and triglyceride concentrations in the fractions were measured enzymatically using Boehringer Mannheim kits. Recoveries of total cholesterol and triglycerides were $90 \%$ and $87 \%$, respectively.

Quantitation of plasma apolipoproteins. Human apo CIII was quantified by rocket immunoelectrophoresis using an anti-human apo CIII antibody that had $<0.01 \%$ cross-reactivity with mouse apo CIII (14). Mouse apo A-I was quantified by rocket immunoelectrophoresis using a polyclonal anti-mouse apo A-I antibody prepared in cynomolgus monkeys generously provided by Dr. George Melchior of the Upjohn Company (18). This antibody had $<0.01 \%$ cross-reactivity with human apo A-I. Human apo A-I was quantified by the turbidity method using a polyclonal goat anti-human apo A-I antibody that had $<0.01 \%$ cross-reactivity with mouse apo A-I (17).

Plasma CETP concentration. Plasma CETP concentration was measured by solid-phase radioimmunoassay as described previously (26).

Preparation of HDL labeled in the apo A-I and cholesteryl ester moieties. Human and mouse apo A-I were purified and radiolabeled with ${ }^{125}$ I by the Bilheimer modification of the McFarlane method, as previously described $(27,28)$. The specific activity of ${ }^{125}$ I-labeled apo A-I was $\sim 200 \mathrm{cpm} / \mathrm{ng}$. $10 \mu \mathrm{Ci}$ of $\left[{ }^{3} \mathrm{H}\right]$ cholesteryl oleoyl ether was placed in a glass tube and the solvent was dried under $\mathrm{N}_{2} .1 \mathrm{ml}$ of 0.15 $\mathrm{M}$ of $\mathrm{NaCl}$ containing $125 \mu \mathrm{g}$ of triacylglycerol (Intralipid Kabi Vitrum Inc., Stockholm, Sweden) was added. The triacylglycerol was labeled with $\left[{ }^{3} \mathrm{H}\right]$ cholesteryl oleoyl ether by sonication 12 times (10 s each) using a sonicator (Branson Ultrasonics Corp., Danbury, CT) at $50 \%$ output in ice cooled water. To label HDL with $\left[{ }^{3} \mathrm{H}\right]$ cholesteryl oleoyl ether, $1 \mathrm{ml}$ of plasma from control or $\mathrm{HuAITg}$ mice was incubated with labeled intralipid ( $125 \mu \mathrm{g}$ of triacylglycerol) and $1 \mathrm{ml}$ of $d>1.25 \mathrm{~g} / \mathrm{ml}$ rabbit plasma (a source of CETP), for $16 \mathrm{~h}$ at $37^{\circ} \mathrm{C}$ as described previously $(18,20)$. The labeled HDL fraction was isolated by sequential ultracentrifugation between $d 1.063$ and $1.21 \mathrm{~g} / \mathrm{ml}$, dialyzed against five changes of 1 liter of $0.9 \% \mathrm{NaCl}, 1 \mathrm{mM}$ EDTA over $20 \mathrm{~h}$ and used 
immediately. 2-4 $\mu \mathrm{g}$ of ${ }^{125} \mathrm{I}$-mouse or human apo A-I was mixed with $100,000-200,000 \mathrm{dpm}\left(10-20 \mu \mathrm{g}\right.$ of HDL-C) of the $\left[{ }^{3} \mathrm{H}\right]$ cholesteryl oleoyl ether labeled mouse or HuAITg HDL before injection of HuCIIITg and HuCIIICETPTg or HuAICIIITg and HuAICIIICETPTg mice, respectively. This procedure was associated with a $>90 \%$ recovery of both $\left[{ }^{3} \mathrm{H}\right]$ cholesteryl oleoyl ether and ${ }^{125} \mathrm{I}$-apo A-I in the plasma $10 \mathrm{~min}$ after the injection $(18,20,29)$.

In vivo turnover studies. Methoxyflurane anesthetized mice were injected intravenously (femoral vein) with either control or HuAITg mouse HDL doubly labeled with $2-4 \mu \mathrm{g}$ of ${ }^{125} \mathrm{I}$-mouse or human apo A-I, respectively, and $100,000-200,000 \mathrm{dpm}$ of $\left[{ }^{3} \mathrm{H}\right]$ cholesteryl oleoyl ether, as previously described $(18,20)$. The injected HDL mass was $<5 \%$ of the mouse HDL pool. Blood $(50 \mu \mathrm{l})$ was taken from the retroorbital plexus under anesthesia with methoxyflurane at 10 and 90 min, and 3, 8, and $28 \mathrm{~h}$ for determination of radioactivity. The FCRs for apo A-I and HDL cholesteryl oleoyl ether were calculated from the plasma decay curves of ${ }^{125}$ I-apo A-I and $\left[{ }^{3} \mathrm{H}\right]$ cholesteryl oleoyl ether assuming a two-pool model by the Matthews method (30).

In vivo apo A-I labeling study. The rate of appearance of apo A-I in the plasma was determined as follows. $100 \mu \mathrm{Ci}$ of $\left[{ }^{35} \mathrm{~S}\right]$ methionine (Translabel, ICN Biomedicals, Costa Mesa, CA) in $200 \mu$ l sterile saline was injected in the femoral vein of methoxyflurane anesthetized mice. Approximately $100 \mu$ l of blood was obtained via retroorbital bleeding, as described above, at 10,20,30, and $40 \mathrm{~min}$. Plasma was isolated via centrifugation and incorporation of $\left[{ }^{35} \mathrm{~S}\right]$ methionine into albumin and mouse apo A-I were determined via immunoprecipitation, using rabbit anti-mouse albumin antibody and monkey anti-mouse apo A-I antibody, respectively. The eluted proteins were subjected to PAGE after adding SDS-buffer on $12.5 \%$ gels with $8 \%$ stacking gels. The gels were then treated with Enhance (New England Nuclear, Boston, MA), dried and then exposed to x-ray film (XAR, Eastman Kodak Co., Rochester, $\mathrm{NY}$ ) for $5 \mathrm{~d}$. Bands corresponding to apo A-I ( $28 \mathrm{kD}$ ) and albumin (67 kD) were quantified using a laser scanner (LKB Ultroscan XL Laser Densitometer).

Apo A-I mRNA quantitation. Mouse apo A-I mRNA levels were quantified by a solution hybridization RNase protection assay with a riboprobe to detect mouse apo A-I mRNA, as previously.described (31, 32). With the animals allowed free access to food and water liver and small intestine were taken from control and HuCIIITg mfoe. RNA was isolated by the method of Chomczynski and Sacchi (33). (B. ckground counts per minute for the probe was routinely $<0.4 \%$ of total counts using the filter counting assay.

Statistical analysis. Results are expressed as mean $\pm \mathrm{SE}$ of the mean. The Student $t$ test was used to compare differences between groups. Statistical significance was defined as $P<0.05$.

\section{Results}

Several types of transgenic mice were used to study the influence of hypertriglyceridemia in the presence or absence of CETP on HDL-C levels. The hypertriglyceridemic HuCIIITg mouse line 3707 was crossed with the HuCETPTg mouse line and measurements of lipids, lipoproteins, apolipoproteins, and CETP mass were made with animals ingesting a Chow + zinc $(25 \mathrm{mM})$ diet. In preliminary experiments the addition of zinc to the diet was shown to have no significant effect on the lipoprotein profile in the HuCIIITg mice, whereas it maximizes the effect of the MMTH I-driven CETP transgene in the HuCIIICETPTg mice. A comparison of the HuCIIITg and the HuCIIICETPTg mice is shown in Table I. Both types of animals had triglycerides in the $600-700 \mathrm{mg} / \mathrm{dl}$ range. The HuCIIICETPTg mice had a CETP mass of $2.8 \mu \mathrm{g} / \mathrm{ml}$. Compared to HuCIIITg mice, HuCIIICETPTg mice had $48 \%$ lower HDL-C ( $44 \pm 2$ vs. $23 \pm 2 \mathrm{mg} / \mathrm{dl}, P<0.0001)$ and $40 \%$ lower mouse apo A-I ( $141 \pm 6$ vs. $85 \pm 3 \mathrm{mg} / \mathrm{dl}, P<0.0001$ ).

Owing to the different metabolic properties of HDL in HuAITg versus control mice, the triglyceride-HDL-C relationship was also studied in transgenic mice expressing human apo A-I. In these experiments the hypertriglyceridemic HuAICIIITg mouse lines were crossed with the HuCETPTg mouse line and measurements were made as above and are also shown in Table I. HuAICIIITg and HuAICIIICETPTg mice had triglycerides in the $620-745 \mathrm{mg} / \mathrm{dl}$ range. The HuAICIIICETPTg mice had a CETP mass of $2.6 \mu \mathrm{g} / \mathrm{ml}$. Compared to HuAICIIITg mice, the HuAICIIICETPTg mice had $61 \%$ lower HDL-C ( $41 \pm 3$ vs. $16 \pm 1 \mathrm{mg} / \mathrm{dl}, P<0.0001), 43 \%$ lower human apo A-I ( $141 \pm 13$ vs. $81 \pm 7 \mathrm{mg} / \mathrm{dl}, P<0.0001)$, and $56 \%$ lower mouse apo A-I ( $36 \pm 6$ vs. $16 \pm 4 \mathrm{mg} / \mathrm{dl}, P<0.0001)$.

The plasma lipoprotein profiles of HuCIIITg, HuCIIICETPTg, HuAICIIITg, and HuAICIIICETPTg mice were next evaluated by column aromatography (FPLC). Plasma was subjected to chromatography on Superose 6 and cholesterol and triglycerides were measured in each column fraction. The results are shown in Fig. 1. As can be seen, af four types of animals had gver $90 \%$ of their triglycerides in the VLDL fraction. The triglyceride to cholesterol ratio in this fraction was typical of VLDL. In the presence of CETP there was a significant decrease in the HDL-C. These results are compatible with those shown in Table I based on ultracentrifugation.

Nondenaturing gradient gel electrophoresis was then used to study the effects of hypertriglyceridemia in the presence and absence of CETP on HDL particle size distribution. In Fig. 2, panels $A, B$, and $C$ compare control, HuCIIITg, and HuCIIICETPTg mouse HDL, respectively, and panels $D, E$, and $F$ compare HuAITg, HuAICIIITg, and HuAICIIICETPTg mouse HDL, respectively. Control mouse HDL is primarily monodisperse, with a particle diangetef of $9.8 \mathrm{~nm}$. Hypertriglyceridemic HuCIIITg mouse HDL is similar with a diameter of $9.8 \mathrm{~nm}$. However, in the presence of both hypertriglyceridemia

Table I. Lipoproteins and Apolipoproteins in HuCIIITg, HuCIIICETPTg, HUAICIIITg, and HuAICIIICETPTg Mice

\begin{tabular}{|c|c|c|c|c|c|c|c|}
\hline Mice & $\mathrm{Tg}$ & TC & HDL-C & Human A-I & Mouse A-I & Human CIII & CETP mass \\
\hline & \multicolumn{6}{|c|}{$m g / d l$} & $\mu g / d l$ \\
\hline HuCIIITg $(n=14)$ & $699 \pm 53$ & $118 \pm 4$ & $44 \pm 2$ & - & $141 \pm 6$ & $21.5 \pm 1.0^{*}$ & - \\
\hline HuCIIICETPTg $(n=19)$ & $592 \pm 53$ & $98 \pm 11$ & $23 \pm 2^{\ddagger}$ & - & $85 \pm 3^{\ddagger}$ & $17.6 \pm 1.5^{*}$ & $2.8 \pm 0.2$ \\
\hline HuAICIIITg $(n=15)$ & $745 \pm 148$ & $126 \pm 24$ & $41 \pm 3$ & $141 \pm 13$ & $36 \pm 6$ & $17.1 \pm 3.0$ & - \\
\hline HuAICIIICETPTg $(n=17)$ & $620 \pm 110$ & $83 \pm 15$ & $16 \pm 1^{\ddagger}$ & $81 \pm 7^{\ddagger}$ & $16 \pm 4$ & $11.9 \pm 3.0$ & $2.6 \pm 0.2$ \\
\hline
\end{tabular}

Animals ingested a Chow $+\operatorname{zinc}(25 \mathrm{mM})$ diet. TC, total cholesterol; $\mathrm{Tg}$, triglyceride. ${ }^{*} P<0.05 .^{\ddagger} P<0.0001$. 


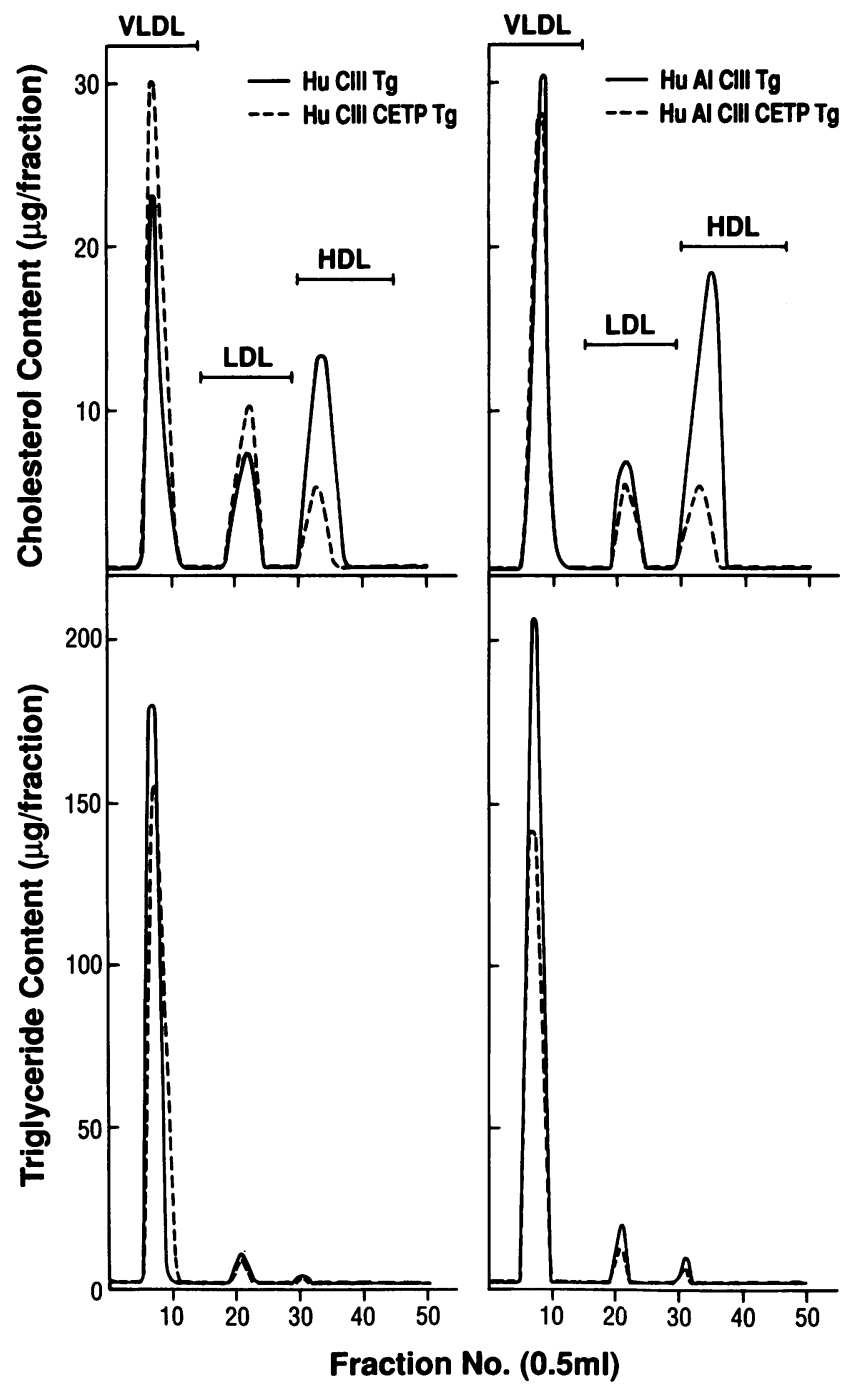

Figure 1. FPLC analysis of lipoproteins. Aliquots $(200 \mu \mathrm{l})$ of plasma from HuCIIITg, HuCIIICETPTg, HuAICIIITg, and HuAICIIICETPTg mice were loaded into a 500- $\mu$ l teflon sample loop for application to two Superose 6 columns connected in series. Lipoproteins were eluted at $0.3 \mathrm{ml} / \mathrm{min}$ with $1 \mathrm{mM}$ EDTA and $154 \mathrm{mM} \mathrm{NaCl}$. After the initial $12 \mathrm{ml}$ had eluted, 50 fractions $(0.5 \mathrm{ml})$ were collected. Cholesterol and triglyceride concentrations were measured in each fraction. All four types of animals had over $90 \%$ of their triglycerides in the VLDL fraction. In the presence of CETP the cholesterol content of HDL was lower in both HuCIIICETPTg and HuAICIIICETPTg compared with HuCIIITg and HuAICIIITg mice, respectively.

and CETP, the HuCIIICETPTg mouse HDL is smaller with a particle diameter of $8.8 \mathrm{~nm}$. HuAITg mouse HDL is polydisperse with two principal particle diameters of 10.3 and 9.1, corresponding to human $\mathrm{HDL}_{2 b}$ and $\mathrm{HDL}_{3 \mathrm{a}}$. In the hypertriglyceridemic HuAICIIITg mice there is a relative decrease in larger, $\mathrm{HDL}_{2 \mathrm{~b}}$, and increase in smaller, $\mathrm{HDL}_{3 \mathrm{~b}}$ and $\mathrm{HDL}_{3 \mathrm{c}}$, particles. Finally, when both hypertriglyceridemia and CETP are present, as in the HuAICIIICETPTg mice, all larger HDL species are absent and the only $\mathrm{HDL}$ appears to be $\mathrm{HDL}_{3 \mathrm{c}}$ with a particle diameter of $7.6 \mathrm{~nm}$. Thus, hypertriglyceridemia in the absence of CETP has an effect on particle size only on the background of human apo A-I. However, hypertriglyceridemia in the presence of CETP is associated with a reduction in HDL particle size whether on the mouse or human apo A-I genetic background.

To elucidate the metabolic basis for the changes in HDL-C and apo A-I levels induced by hypertriglyceridemia with or without CETP, HDL turnover studies were performed. HDL doubly labeled with ${ }^{125} \mathrm{I}$-apo A-I and $\left[{ }^{3} \mathrm{H}\right]$ cholesteryl oleyl ether was injected intravenously into HuCIIITg, HuCIIICETPTg, HuAICIIITg, and HuAICIIICETPTg mice and the plasma disappearance of radioactivity followed, as shown in Fig. 3. The Matthews method was used to calculate HDL CE FCR and apo A-I FCR and these multiplied by the pool size (as reflected by the plasma concentration of HDL CE and total apo A-I, respectively) estimated the transport rates (TR). These results are summarized in Table II. Compared with HuCIIITg mice, the HuCIIICETPTg mice had a 65\% higher HDL CE FCR, which accounted for most of the decrease in HDL-C levels. Similarly, compared with HuAICIIITg mice, the HuAICIIICETPTg mice had a $107 \%$ increase in HDL CE FCR which also accounted for most of the HDL-C decrease. CETP expression significantly decreased HDL CE TR in the HuCIIICETPTg animals, but in the HuAICIIICETPTg animals the effect was not significant. With regard to apo A-I, on the mouse apo A-I background CETP significantly increased apo A-I FCR $15 \%$ and decreased apo A-I TR 29\%. On the human apo A-I background, CETP significantly increased apo A-I FCR $35 \%$ and decreased apo A-I TR 48\%. Thus, in both cases the decrease in apo A-I levels was due to changes in both FCR and TR, with the latter perhaps contributing more than the former.

These experiments with transgenic mice clearly show that CETP is a major mediator of the inverse relationship between triglyceride and HDL-C level. However, in performing these experiments it was unexpectedly noted that this relationship also existed in the absence of CETP. The triglyceride-HDL-C relationship is shown in Fig. 4 for the HuCIIITg line 3707 in the presence and absence of CETP. The regression line is steeper and shifted to the left in the presence of CETP (at the same level of triglycerides lower HDL-C levels). The inverse correlation of triglycerides and HDL-C levels in the absence of CETP was seen within several different HuCIIITg lines and also between lines with different amounts of apo CIII expression and differing triglyceride levels. In four different HuCIIITg lines as the triglyceride levels increased, HDL-C levels decreased (Table III). This was particularly apparent with the high expressor HuCIIITg line 2721 with triglycerides of $\sim 1,200 \mathrm{mg} / \mathrm{dl}$, in which HDL-C averaged $34 \pm 2 \mathrm{mg} / \mathrm{dl}$ compared with control mice with triglycerides of $96 \pm 5 \mathrm{mg} / \mathrm{dl}$ and HDL-C of $54 \pm 2 \mathrm{mg} / \mathrm{dl}$. A more complete comparison of lipid, lipoprotein and apolipoprotein levels between control and HuCIIITg line 2721 mice is shown in Table IV. The respective lipoprotein profiles were confirmed by FPLC column chromatography (data not shown). It is apparent both by ultracentrifugation and column chromatography that in hypertriglyceridemia in the absence of CETP, the HDL is diminished. Doubly labeled HDL turnover studies were performed to determine the metabolic basis for this observation and the results are summarized in Table V. As can be seen, the HDL CE FCR is not increased in the HuCIIITg mice compared to controls; if anything, there is a slight but insignificant decrease. Therefore, the decrease in HDL-C levels in HuCIIITg mice is exclusively due to a decrease in the HDL CE TR (47\%). With regard to the apo A-I kinetics, in HuCIIITg mice there is a slight increase in the 

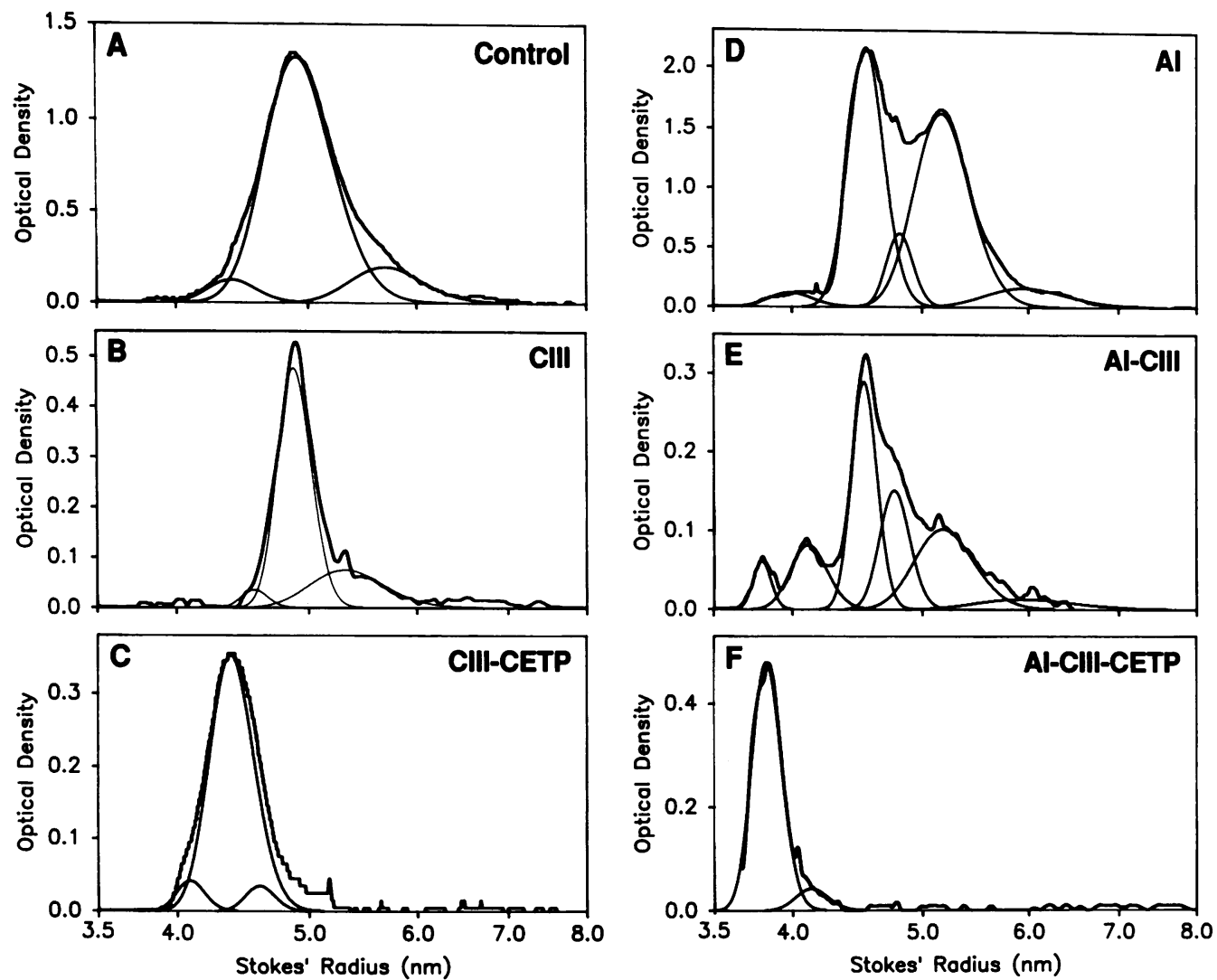

Figure 2. The effects of hypertriglyceridemia in the presence and absence of CETP on HDL particle size distribution. Scans of native gradient gel electrophoretogram (4-30\%) of $30 \mu \mathrm{l}$ of $d$ $<1.21 \mathrm{~g} / \mathrm{ml}$ fraction were analyzed by Gaussian modeling. The major lines are the actual scans, whereas the minor lines indicate the component populations of particles as determined by the Gaussian modeling. As can be seen, control mouse HDL consists primarily of a single size population $(A)$. Hypertriglyceridemic HuCIIITg mouse HDL is similar $(B)$, however, HuCIIICETPTg mouse HDL particle size is smaller $(C)$. HuAITg mouse HDL consist primarily of two distinct HDL subpopulations $(D)$. In the hypertriglyceridemic HuAICIIITg mice there is a relative decrease in larger $\mathrm{HDL}_{2 \mathrm{~b}}$, and a relative increase in smaller $\mathrm{HDL}_{3 \mathrm{~b}}$ and

$\mathrm{HDL}_{3 \mathrm{c}}$ particles $(E)$, while in HuAICIIICETPTg mice all larger HDL species are absent and the only HDL appear to be HDL $\mathrm{H}_{3 \mathrm{c}}(F)$. The scans show the results from individual mice, although the patterns shown were reproduced in three mice from each category.

apo A-I FCR (13\%) which accounts for only a small fraction of the $52 \%$ decrease in apo A-I levels. This implies that hypertriglyceridemia decreases the apo A-I TR as well as the HDL CE TR and in this manner lowers HDL-C levels.

To confirm this observation of lower apo A-I transport rate in HuCIIITg mice, an in vivo labeling experiment with $\left[{ }^{35} \mathrm{~S}\right]$ methionine was performed in both control and $\mathrm{HuCIIITg}$ mice and the incorporation of $\left[{ }^{35} \mathrm{~S}\right]$ methionine into apo A-I was measured by immunoprecipitation of apo A-I from plasma taken at 10,20,30, and $40 \mathrm{~min}$ after the intravenous injection of $\left[{ }^{35} \mathrm{~S}\right]$ methionine. As shown in Fig. 5, the incorporation of $\left[{ }^{35}\right.$ S $]$ methionine into apo A-I in HuCIIITg animals is $~ 50 \%$ of that of control animals, indicating lower appearance of apo A-I in the plasma in the former group.

From both the in vivo turnover and in vivo labeling studies, it seems that HuCIIITg mice have lower apo A-I synthetic rates compared to controls. To examine whether this reduction is transcriptional, mouse apo A-I mRNA levels were measured in total RNA isolated from liver and small intestine of both control and HuCIIITg mice (line 2721) by a solution hybridization/RNase protection assay using mouse apo A-I mRNA specific riboprobes. As shown in Table VI, intestinal mouse apo A-I mRNA levels were reduced significantly in HuCIIITg compared to control mice, while the hepatic mouse apo A-I mRNA levels were unchanged. This suggests that the reduction of mouse apo A-I levels in HuCIIITg mice (line 2721) might be mediated in part by modulation of intestinal apo A-I synthesis. There was no significant difference in the rate of appearance of $\left[{ }^{35}\right.$ S $]$ methionine into albumin between the two groups (see Fig. 5 , legend).

Table II. HDL Metabolism in HuCIIITg, HuCIIICETPTg, HuAICIIITg, and HuAICIIICETPTg Mice

\begin{tabular}{lcccccc}
\hline & HDL-C & HDL CE FCR & HDL CE TR & Apo A-I & A-I FCR & A-I TR \\
\hline & $m g / d l$ & pools $/ h$ & $U$ & $m g / d l$ & pools $/ h$ \\
HuCIIITg $(n=4)$ & $44 \pm 2$ & $0.175 \pm 0.008$ & $5.3 \pm 0.3$ & $134 \pm 5$ & $0.118 \pm 0.005$ & $15.8 \pm 0.5$ \\
HuCIIICETPTg $(n=4)$ & $23 \pm 1^{\S}$ & $0.288 \pm 0.020^{*}$ & $3.6 \pm 0.3^{*}$ & $83 \pm 4^{\S}$ & $0.136 \pm 0.002^{*}$ & $11.3 \pm 0.6^{\ddagger}$ \\
HuAICIIITg $(n=5)$ & $42 \pm 4$ & $0.164 \pm 0.009$ & $4.7 \pm 0.4$ & $210 \pm 35$ & $0.124 \pm 0.007$ & $25.9 \pm 3.7$ \\
HuAICIIICETPTg $(n=5)$ & $19 \pm 2^{\S}$ & $0.340 \pm 0.040^{\S}$ & $3.6 \pm 0.5$ & $81 \pm 11^{\S}$ & $0.168 \pm 0.004^{\ddagger}$ & $13.5 \pm 1.5^{\ddagger}$
\end{tabular}

${ }^{*} P<0.05$ compared to litter mates. ${ }^{\ddagger} P<0.005$ compared to litter mates. ${ }^{\S} P<0.001$ compared to litter mates. 


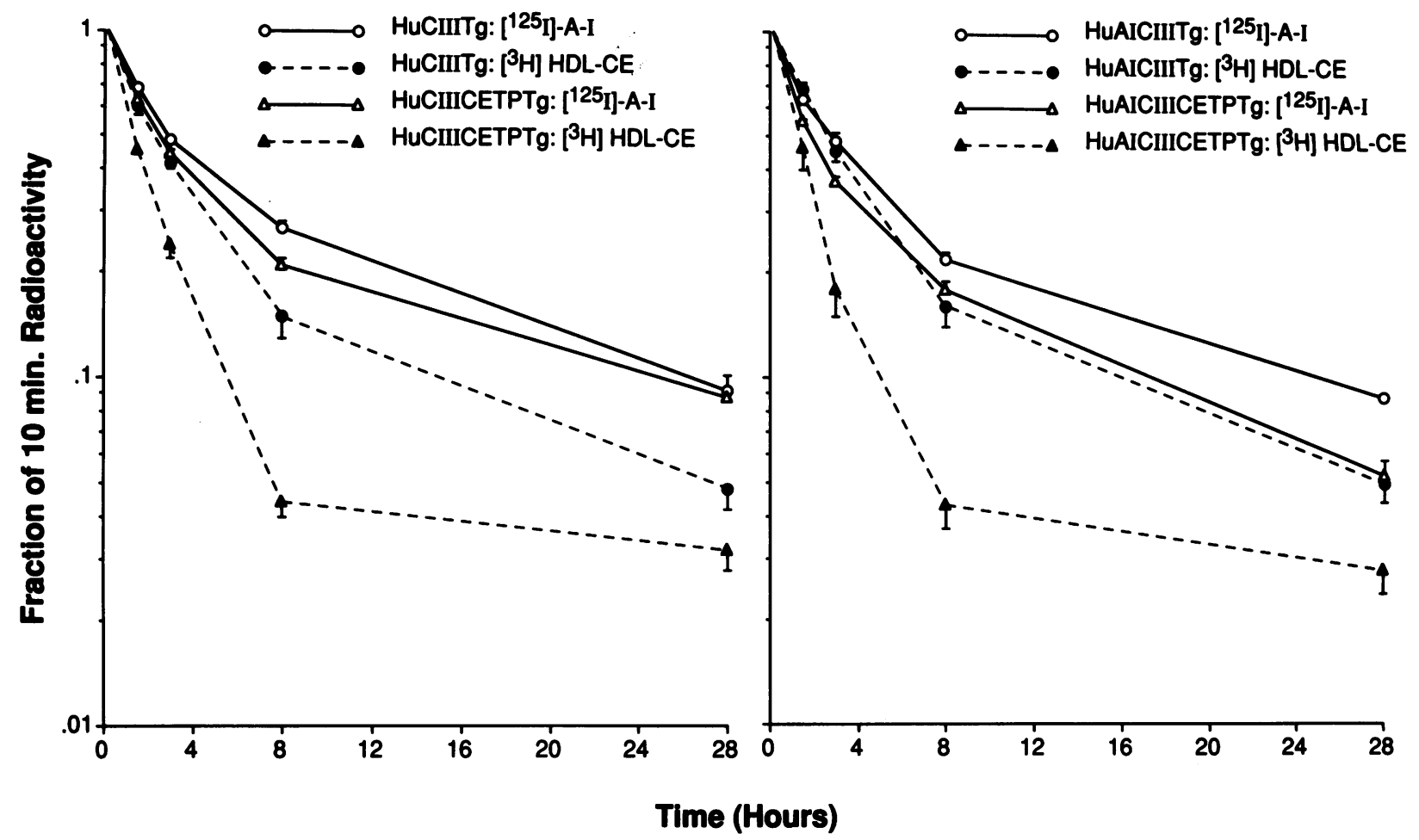

Figure 3. Radioactive plasma decay curves for doubly labeled HDL in HuCIIIT, HuCIIICETPTg, HuAICIITT, and HuAICIIICETPTg mice. Mice were injected intravenously with either control or HuAITg mouse HDL doubly labeled with ${ }^{125} \mathrm{I}-$ mouse or human apo A-I, respectively, and $\left[{ }^{3} \mathrm{H}\right]$ cholesteryl oleoyl ether. Blood $(50 \mu \mathrm{l})$ was then taken from the retroorbital plexus at 10 and 90 min, and 3,8 , and $28 \mathrm{~h}$ for determination of radioactivity. HuCIIIT and HuCIIICETPTg mice were injected with doubly labeled control mouse HDL and the radioactivity in plasma is shown (left panel). As can be seen, the disappearance of HDL CE radioactivity is greater than for apo A-I in both HuCIIITg and HuCIIICETPTg mice. Compared to HuCIIITg, HuCIIICETPTg mice show a large increase in HDL CE FCR and a small increase in apo A-I FCR. HuAICIIITg and HuAICIIICETPTg mice were injected with doubly labeled HuAITg mouse HDL, and radioactivity in plasma is shown (right panel). As can be seen, the disappearance of HDL CE radioactivity is greater than for apo A-I in both HuAICIIITg and HuAICIIICETPTg mice. Compared to HuAICIIITg, HuAICIIICETPTg mice show a large increase in HDL CE FCR and a modest increase in apo A-I FCR.

\section{Discussion}

In humans there is a well-known association of high triglycerides with low HDL-C levels (1-10). This relationship is thought, but not proven, to arise from core lipid exchange be- tween triglyceride-rich lipoproteins and the cholesteryl esters in the core of HDL mediated by CETP $(2-4,13)$. Such exchange has been shown to occur in vitro in reconstituted systems (2-4). In addition, in vivo it has been shown that plasma CETP activity correlates with core lipid exchange between VLDL and

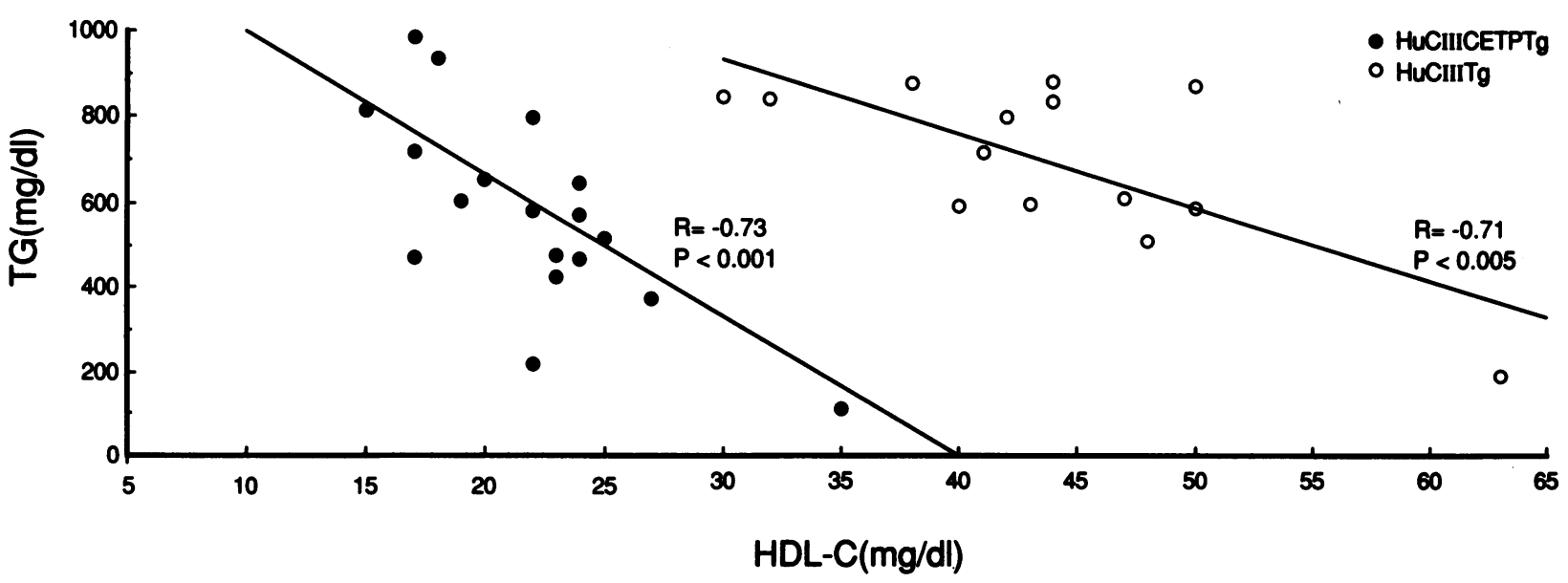

Figure 4. Triglyceride-HDL-C relationship in HuCIIITg (line 3707) in the presence and absence of CETP. The regression line is steeper and shifted to the left in the presence of CETP (at the same level of triglycerides lower HDL-C levels). If the point with the low triglyceride level is excluded from the HuCIIITg group in the absence of CETP, the correlation for this group of animals loses significance. 
Table III. Triglyceride-HDL-C Relationship in Different Lines of HuCIIITg Mice

\begin{tabular}{|c|c|c|}
\hline Mouse line & Triglyceride & HDL-C \\
\hline & \multicolumn{2}{|c|}{$m g / d l$} \\
\hline Control $(n=26)$ & $96 \pm 5$ & $54 \pm 2$ \\
\hline HuCIIITg $2674(n=11)$ & $252 \pm 22$ & $50 \pm 2$ \\
\hline HuCIIITg $3641(n=4)$ & $478 \pm 26$ & $47 \pm 2$ \\
\hline HuCIIITg $3707(n=9)$ & $744 \pm 39$ & $41 \pm 3$ \\
\hline HuCIIITg $2721(n=30)$ & $1192 \pm 55$ & $34 \pm 2$ \\
\hline
\end{tabular}

HDL in the plasma of hypertriglyceridemic patients (34), and that CETP infusion into hypertriglyceridemic sucrose-fed rats lowers HDL-C levels and particle sizes (13).

The current study in transgenic mice provides direct proof of the important role of CETP in the high-triglyceride-lowHDL-C level relationship. Hypertriglyceridemia was produced in mice by overexpression of the human apo CIII gene. The major metabolic mechanism in these mice appears to be reduced VLDL FCR (15). At this time we cannot be certain if the effects of hypertriglyceridemia that were observed are mechanism-specific, in that this is the only available model of mouse hypertriglyceridemia in the absence of other major metabolic disturbances (i.e., diabetes). The coexpression of hypertriglyceridemia and CETP showed an additive effect on HDL-C levels (Fig. 4 and Table I) and a strong interactive effect to decrease apo A-I levels (Table I). However, in the case of HDL particle size, hypertriglyceridemia or CETP expression alone had minimal effect on HDL particle size, but when coexpressed revealed a profound interaction (Fig. 1). This may reflect a need for triglyceride enrichment of HDL for hepatic lipase to decrease HDL size (3). In addition, in the absence of CETP we did observe an inverse relationship of triglycerides and HDL-C levels. This was most apparent in animals with marked hypertriglyceridemia (Table III) and appears to involve decreased HDL CE and apo A-I TR. In homozygous CETP-deficient patients, an inverse relationship of triglycerides and HDL-C levels was not observed (35). However, these individuals had triglyceride levels $<400 \mathrm{mg} / \mathrm{dl}$, which may not have been high enough to observe this relationship. Finally, although this was not addressed in the current study, recently another group created CETP transgenic mice and found that decreased HDL-C was accompanied by increased VLDL-C and LDL-C levels, as expected from studies in humans (35-37).

In hypertriglyceridemic humans low HDL-C levels are associated with a reduction in HDL particle size $(2,3)$. The basis for this association was explored in the transgenic mouse model. In control mice HDL consists primarily of a single particle size distribution, diameter $10 \mathrm{~nm}$; in hypertriglyceridemic HuCIIITg mice the particle diameter is unchanged. In a previous study we noted that the introduction of CETP into normotriglyceridemic mice reduced HDL particle diameter to 9.7 $\mathrm{nm}(16,20)$. However, in the current study the combined effect of hypertriglyceridemia and CETP in the HuCIIICETPTg mice reduced HDL particle diameter to $8.8 \mathrm{~nm}$, demonstrating that the effect of hypertriglyceridemia on HDL particle size in the mouse is mediated virtually completely through CETP with a large synergistic effect.

Although interesting, these studies in the mouse of the association of hypertriglyceridemia with small HDL suffer from the fact that mouse HDL particle size distribution (monodisperse) is unlike humans. Normotriglyceridemic humans typically have two main HDL particle size distributions: $\mathrm{HDL}_{2 \mathrm{~b}}$, diameter $10.8 \mathrm{~nm}$, and $\mathrm{HDL}_{3 \mathrm{a}}$, diameter $9.0 \mathrm{~nm}$ (24). In hypertriglyceridemic humans the larger $\mathrm{HDL}_{2 \mathrm{~b}}$ tend to diminish with the appearance of smaller HDL species, such as $\mathrm{HDL}_{3 \mathrm{~b}}$, diameter $8.4 \mathrm{~nm}$, and $\mathrm{HDL}_{3 \mathrm{c}}$, diameter $7.8 \mathrm{~nm}$ (2). The biochemical basis for the difference in HDL particle size distribution between mouse and human was revealed by previous transgenic mouse experiments (18). HuAITg mice, in which human apo A-I virtually replaces mouse apo A-I, show HDL particle size distribution similar to humans, implicating the physical differences between human and mouse apo A-I as the underlying basis for the species differences. Therefore, it was of interest to study the high-triglyceride-small-HDL association in the mouse on the background of human apo A-I. In HuAITg mice $\mathrm{HDL}_{2 \mathrm{~b}}$, diameter $10.3 \mathrm{~nm}$, and $\mathrm{HDL}_{3 \mathrm{a}}$, diameter $9.1 \mathrm{~nm}$, were observed, as before (18). In hypertriglyceridemic HuAICIIITg mice there was a diminution of the $\mathrm{HDL}_{2 \mathrm{~b}}$ and the appearance of $\mathrm{HDL}_{3 \mathrm{~b}}$, diameter $8.3 \mathrm{~nm}$, and $\mathrm{HDL}_{3 \mathrm{c}}$, diameter $7.6 \mathrm{~nm}$. Thus, on the background of human apo A-I, hypertriglyceridemia alone shifted the HDL to smaller particle size distribution. Finally, the most striking effect of all was achieved with the combined effect of hypertriglyceridemia and CETP in the HuAICIIICETPTg mice. All large HDL disappeared, with only $\mathrm{HDL}_{3 \mathrm{c}}$, particle size $7.6 \mathrm{~nm}$, remaining. This is quite comparable to HDL size seen in humans with triglycerides $>500 \mathrm{mg} / \mathrm{dl}$ (2) and proves that this phenotype is due to a triglycerideCETP interaction.

The high-triglyceride-low-HDL-C level lipoprotein pattern is associated with atherosclerosis susceptibility $(5,38)$. One proposed mechanism is that there is diminished reverse cholesterol transport of HDL CE from the artery wall to the liver (39). Although our measurement of HDL CE TR cannot be assumed to be totally due to unidirectional flux of cholesterol from peripheral tissues to the liver, it was of interest to examine

Table IV. Lipoproteins and Apolipoproteins in HuCIIITg (2721 Line) and Controls

\begin{tabular}{|c|c|c|c|c|c|c|c|}
\hline & $\mathrm{Tg}$ & TC & HDL-C & LDL-C & VLDL-C & Mouse A-I & Human CIII \\
\hline & & & & $m g / d l$ & & & \\
\hline Control mice $(n=26)$ & $96 \pm 5$ & $72 \pm 2$ & $54 \pm 2$ & $7 \pm 1$ & $11 \pm 1$ & $145 \pm 9$ & - \\
\hline HuCIIITg $2721(n=30)$ & $1192 \pm 55^{\ddagger}$ & $182 \pm 10^{\ddagger}$ & $34 \pm 2 *$ & $15 \pm 7^{*}$ & $133 \pm 13^{\ddagger}$ & $83 \pm 6^{\ddagger}$ & $37.8 \pm 1.4$ \\
\hline
\end{tabular}

TC, total cholesterol; Tg, triglyceride. ${ }^{*} P<0.001$ compard to control mice. ${ }^{\ddagger} P<0.0001$ compard to control mice. 
Table V. HDL Metabolism in HuCIIITg (2721 Line) and Controls

\begin{tabular}{lcccccc}
\hline & HDL-C & HDL CE FCR & HDL CE TR & Apo A-I & Apo A-I FCR & Apo A-I TR \\
\hline & $m g / d l$ & $p o o l s / h$ & $U$ & $m g / d l$ & pools/h \\
Control mice $(n=6)$ & $54 \pm 2$ & $0.21 \pm 0.008$ & $8.5 \pm 0.5$ & $145 \pm 9$ & $0.114 \pm 0.002$ & $16.5 \pm 2$ \\
HuCIIITg mice $(n=6)$ & $30 \pm 2^{\ddagger}$ & $0.19 \pm 0.02$ & $4.5 \pm 0.5^{\ddagger}$ & $69 \pm 5^{\S}$ & $0.129 \pm 0.004^{*}$ & $8.9 \pm 1.6^{\ddagger}$ \\
\hline
\end{tabular}

${ }^{*} P<0.005$ compared to control mice. ${ }^{\ddagger} P<0.001$ compared to control mice. ${ }^{\S} P<0.0001$ compared to control mice.

the effects of hypertriglyceridemia with or without CETP on the flux of HDL CEs in these animals. In the current study and previous ones $(18,20)$, control mouse HDL CE FCR was 0.21 , 0.20, and 0.22 pools per hour and HDL CE TR 8.5, 7.3 and 9.6 U. In the hypertriglyceridemic HuCIIITg mouse line 3707 (triglycerides $\sim 700 \mathrm{mg} / \mathrm{dl}$ ) HDL CE FCR was 0.18 and HDL CE TR $5.3 \mathrm{U}$; in the HuCIIITg mouse line 2721 (triglycerides $\sim 1,200 \mathrm{mg} / \mathrm{dl}$ ) HDL CE FCR was 0.19 and HDL CE TR 4.5 $\mathrm{U}$. Thus, on the background of mouse apo A-I, hypertriglyceridemia did not change the HDL CE FCR (it certainly did not increase it), but there was a tendency to decrease HDL CE TR, especially at high triglyceride levels.

On the background of human apo A-I, we previously showed that HDL CE FCR was considerably diminished owing to a loss of the selective uptake pathway.(18). In previous studies HuAITg mouse HDL CE FCR was found to be 0.12 and 0.09 pools per hour and HDL CE TR 8.2 and $7.5 \mathrm{U}(18,20)$. In the hypertriglyceridemic HuAICIIITg mice (triglycerides $\sim 700 \mathrm{mg} / \mathrm{dl}$ ) HDL CE FCR increased by $60 \%$ to 0.16 and the HDL CE TR was reduced by $40 \%$ to $4.7 \mathrm{U}$. Thus, on the back-

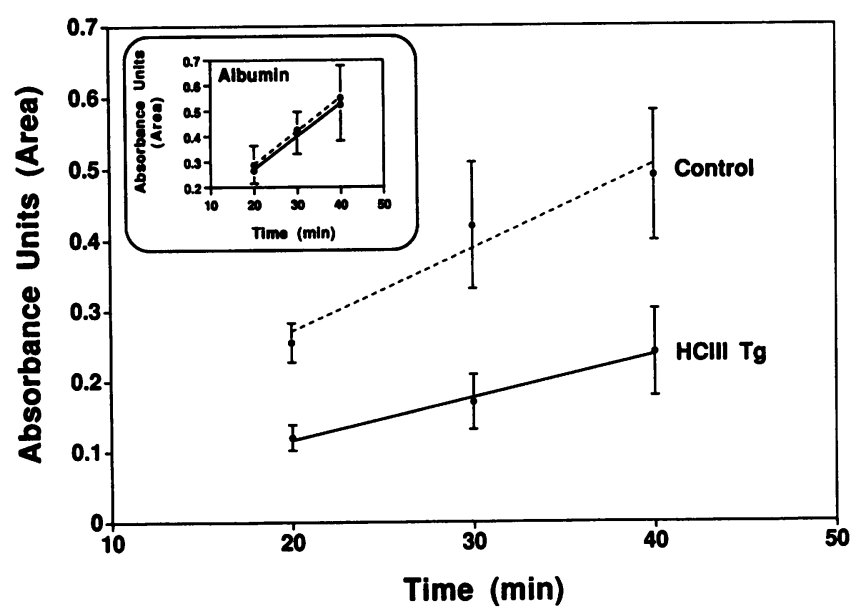

Figure 5. In vivo labeling of apo A-I with $\left[{ }^{35} \mathrm{~S}\right]$ methionine in control and HuCIIITg mice (line 2721). $100 \mu \mathrm{Ci}$ of $\left.{ }^{35} \mathrm{~S}\right]$ methionine was injected intravenously into mice. Blood $(100 \mu \mathrm{l})$ was taken from the retroorbital plexus at 10, 20,30, and $40 \mathrm{~min}$. Plasma was isolated and incorporation of $\left[{ }^{35}\right.$ S]methionine into albumin and mouse apo A-I were determined via immunoprecipitation using rabbit anti-mouse albumin antibody and monkey anti-mouse apo A-I antibody, respectively. After SDS-PAGE the gels were subjected to autofluorography. The fluorograms were scanned and the bands specific to apo A-I and albumin compared. Each point represents the mean \pm SD of three mice. As shown in the figure, the incorporation of $\left[{ }^{35} \mathrm{~S}\right]$ methionine into apo A-I is significantly lower in HuCIIITg animals compared with control littermates, indicating lower appearance of apo A-I in the plasma in the former group. ground of human apo A-I, hypertriglyceridemia increased the HDL CE FCR with a decrease in HDL CE TR. One possible explanation for the hypertriglyceridemia induced increase in HDL CE FCR in the human but not the mouse background is the change in HDL particle size distribution seen in the former, but not the latter (Fig. $2, D$ vs. $E$, and $A$ vs. $B$, respectively). Another explanation could be that the HuAICIITg mice have increased HDL CE FCR compared to the HuAITg mice previously studied. This could be because the current HuAICIIITg line has less human and more mouse apo A-I than the previously studied HuAITg line, and thereby may have preserved some of the selective uptake of HDL CE observed in control mice (18). It also appears that moderate to severe hypertriglyceridemia may reduce the flux of CE through the HDL pathway, and this may contribute to the atherogenic nature of the hightriglyceride-low-HDL-C level phenotype. In fact, in the hypertriglyceridemic HuCIIITg mouse line 2721, the entire reduction of HDL-C observed could be attributed to a decrease in HDL CE TR.

In hypertriglyceridemic mice of both mouse and human apo A-I backgrounds, the addition of CETP markedly increased the HDL CE FCR to 0.29 and 0.34 pools per hour, respectively, with a $25-30 \%$ decrease in HDL CE TR. The increase in HDL CE FCR is accounted for by the introduction by CETP of a new pathway for HDL CE removal which presumably involves the transfer of HDL CE to triglyceride-rich lipoproteins with faster clearance than that of HDL. The decrease in HDL CE TR was somewhat of a surprise. One might have expected that if CETP was rate limiting in reverse cholesterol transport that its introduction might have raised HDL CE TR. The fact that it did not, implies that in this system, reverse transport is adequate and that HDL-C levels fall in proportion to the increase in HDL CE FCR. In other studies we have shown that a high fat diet increases HDL CE TR (40), and perhaps in such a stress, the presence of CETP might enable greater reverse transport to occur.

The combination of hypertriglyceridemia and CETP causes the mice to have the lowest HDL-C levels reported for this species consuming a Chow diet. The result is even more remarkable for the HuAICIIICETPTg mice, where we would expect

Table VI. Mouse Apo A-I mRNA Levels

\begin{tabular}{lcc}
\hline & Liver & Small intestine \\
\hline & \multicolumn{2}{c}{$p g / \mu g R N A$} \\
Control mice $(n=8)$ & $34.3 \pm 1.0$ & $31.2 \pm 1.8$ \\
HuCIIITg $2721(n=8)$ & $33.3 \pm 1.1$ & $14.1 \pm 1.6^{*}$
\end{tabular}

${ }^{*} P<0.001$. 
apo A-I overproduction by the human apo A-I transgene to raise $\mathrm{HDL}-\mathrm{C}$ levels $(17,18)$. It would be of interest to study atherosclerosis susceptibility in the HuCIIICETPTg and HuAICIIICETPTg animals on various diets to see whether the high-triglyceride-low-HDL-C level phenotype is actually atherogenic.

The current studies also allow an examination of the effect of the hypertriglyceridemia phenotype on HDL particle metabolism through examination of apo A-I turnover. In the current study and previous ones $(18,20)$, control mouse apo A-I FCR was $0.11,0.12$, and 0.10 pools per hour and HuAITg mouse apo A-I FCR was 0.13 and 0.12 pools per hour. On the background of mouse and human apo A-I, adding either apo CIII or CETP, as seen in studies of HuCETPTg, HuAICETPTg, HuCIIITg, and HuAICIIITg mice, produced about a $10 \%$ increase in apo A-I FCR. However, the combined effect of hypertriglyceridemia and CETP further elevated the apo A-I FCR to 0.14 in the HuCIIICETPTg mice and 0.17 in the HuAICIIICETPTg mice. In HDL apolipoprotein turnover studies in humans, we previously showed that apo A-I FCR was best predicted by HDL size $(41,42)$. Inasmuch as in rodents a major site of apo A-I catabolism is the proximal tubules of the kidney (12), a possible mechanism may be that small HDL have enhanced kidney filtration and catabolism of apo A-I. Thus, the diminution of HDL size in the HuCIIICETPTg and HuAICIIICETPTg mice may account for this increase in apo A-I FCR. The lowering of plasma apo A-I levels by hypertriglyceridemia and CETP was only partially accounted for by an increase in apo A-I FCR, and there was a significant component of decreased apo A-I TR. The mechanism of this unexpected finding was further explored in the HuCIIITg mouse line 2721 with severe hypertriglyceridemia. In these animals both in vivo metabolic and labeling studies indicated decreased apo A-I synthesis accompanied by a specific decrease in intestinal but not hepatic apo A-I mRNA levels. Thus, in hypertriglyceridemia there might be a decrease in intestinal apo A-I production. In hypertriglyceridemic humans there is an expanded bile acid pool size $(43,44)$ and this may regulate intestinal apo A-I synthesis, although other mechanisms are certainly possible.

Finally, what are the implications of the transgenic mouse model for understanding the low HDL-C risk factor associated with atherosclerosis susceptibility in humans? In the transgenic mice we showed that high triglycerides act synergistically with CETP to cause low HDL-C levels, reduce HDL particle sizes, increase HDL CE FCR and apo A-I FCR, and decrease HDL $\mathrm{CE}$ and apo A-I TR. Thus, the transgenic mouse model proves that high triglycerides in the presence of CETP in vivo can cause the low HDL-C, diminished HDL particle size, and increased apo A-I FCR phenotype associated with heart disease susceptibility. In a previously published human metabolic study we found that, compared with controls, hypertriglyceridemic low HDL-C patients had increased apo A-I FCR but normal apo A-I TR, and the increased apo A-I FCR correlated strongly with decreased HDL particle size $(41,42)$. In the human study the decrease in apo A-I levels associated with hypertriglyceridemia was only $12 \%$, whereas in the mice it was $\sim 50 \%$. The much greater reduction in mice may be due to the combined effect of hypertriglyceridemia on increasing apo A-I FCR and decreasing apo A-I TR.

Thus, the transgenic mouse model described herein reproduces most aspects of the human condition. However, it is probable that other genes also play a role in the complex pro- cesses that lead to the low HDL-C level phenotype. Evidence for this comes from two types of studies in humans. First, although most individuals with low HDL-C levels have high triglycerides, some do not. We have previously shown that these people, too, have increased apo A-I FCR, normal apo A-I TR, and diminished HDL particle size (41). In addition, in patients with high triglycerides and low HDL-C, normalization of triglycerides by diet and drug therapy does not elevate HDL-C levels in some individuals (45-47). Thus, the low HDL-C, increased apo A-I FCR condition can be caused by mechanisms independent of a primary increase in triglyceride levels, such as primary alterations in lipoprotein and/or hepatic lipase, as suggested by Goldberg et al. (7), Kunsi et al. (48), Kekki (49), and Applebaum-Bowden et al. (50).

\section{Acknowledgments}

The authors thank Ethel Stafford, Ph.D., for her assistance.

This study was supported by the following: National Institutes of Health (NIH) grants HL-33714 and HL-32435 (Jan L. Breslow); Bowman Gray School of Medicine, Arizona Center on Aging, NIH grant AG00414; and NIH grants HL-21006 and HL-43165 (Alan R. Tall).

\section{References}

1. Schaefer, E. J., R. I. Levy, D. W. Anderson, R. N. Danner, H. B. Brewer, and W. C. Blackenwelden. 1978. Plasma triglycerides in regulation of HDL-cholesterol levels. Lancet. ii:391-392.

2. Hopkins, G. J., L. B. Chang, and P. J. Barter. 1985. Role of lipid transfers in the formation of a subpopulation of small high density lipoproteins. J. Lipid Res. 26:218-229.

3. Deckelbaum, R. J., E. Granot, Y. Oschry, L. Rose, and S. Eisenberg. 1984 Plasma triglyceride determines structure-composition in low and high density lipoproteins. Arteriosclerosis. 4:225-231.

4. Nikkila, E. A., M. R. Taskinen, and T. Sane. 1987. Plasma high-density lipoprotein concentration and subfraction distribution in relation to triglyceride metabolism. Am. Heart J. 113:543-548.

5. Austin, M. A. 1991. Plasma triglyceride and coronary heart disease. Arterioscler. Thromb. 11:2-14.

6. Richards, E. G., S. M. Grundy, and K. Cooper. 1989. Influence of plasma triglycerides on lipoprotein patterns in normal subjects and in patients with coronary artery disease. Am. J. Cardiol. 63:1214-1220.

7. Goldberg, I. J., W. S. Blaner, T. M. Vanni, M. Moukides, and R. Ramakrishnan. 1990. Role of lipoprotein lipase in the regulation of high density lipoprotein apolipoprotein metabolism. J. Clin. Invest. 86:463-473.

8. Davis, C. E., D. Gordon, J. La Rosa, P. D. S. Wood, and M. Halperin. 1980. Correlations of plasma high density lipoprotein cholesterol levels with other plasma lipid and lipoprotein concentrations. Circulation. 62:IV-24-IV-30.

9. Gordon, T., W. P. Castelli, M. C. Hjortland, W. B. Kannel, and T. R. Dawber. 1977. High density lipoproteins as a protective factor against coronary heart disease. Am. J. Med. 62:707-714.

10. Albrink, M. J., R. M. Krauss, F. T. Lindgren, and V. D. Groeben. 1980 Inter correlations among high density lipoprotein, obesity and triglycerides in a normal population. Lipids. 15:668-678.

11. Phillips, N. R., R. J. Havel, and J. P. Kane. Serum apolipoprotein A-I levels: relationship to lipoprotein lipid levels and selected demographic variables. Am. J. Epidemiol. 116:302-313.

12. Glass, C. K., R. C. Pittman, G. A. Keller, and D. Steinberg. 1983. Tissue sites of degradation of apoprotein A-I in the rat. J. Biol. Chem. 258:7161-7167.

13. Ha, Y. C., and P. J. Barter. 1986. Effects of sucrose feeding and injection of lipid transfer protein on rat plasma lipoproteins. Comp. Biochem. Physiol. 83B:463-466.

14. Ito, Y., N. Azrolan, A. O'Connell, A. Walsh, and J. L. Breslow. 1990. Hypertriglyceridemia as a result of human apo CIII gene expression in transgenic mice. Science (Wash. DC). 249:790-793.

15. Aalto-Setälä, K., E. A. Fisher, X. Chen, T. Chajek-Shaul, T. Hayek, R. Zechner, A. Walsh, R. Ramakrishnan, H. N. Ginsberg, and J. L. Breslow. 1992. Mechanism of hypertriglyceridemia in human apo CIII transgenic mice: diminished VLDL fractional catabolic rate associated with increased apo CIII and reduced apo $\mathrm{E}$ on the particles. J. Clin. Invest. 90:1889-1900.

16. Agellon, L. B., A. Walsh, T. Hayek, P. Moulin, X. C. Jiang, S. A. Shelanski, J. L. Breslow, and A. R. Tall. 1991. Reduced high density lipoprotein 
cholesterol in human cholesteryl ester transfer protein transgenic mice. J. Biol. Chem. 266:10796-10801.

17. Walsh, A., Y. Ito, and J. L. Breslow. 1988. High levels of human apolipoprotein A-I in transgenic mice result in increased plasma levels of small high density lipoprotein (HDL) particles comparable to human $\mathrm{HDL}_{3}$. J. Biol. Chem. 264:6488-6494.

18. Chajek-Shaul, T., T. Hayek, A. Walsh, and J. L. Breslow. 1991. Human apo A-I expression in transgenic mice alters HDL particle size distribution and diminishes selective uptake of HDL cholesteryl esters. Proc. Natl. Acad. Sci. USA. 88:6731-6735.

19. Rubin, E. M., B. Y. Ishida, S. M. Clift, and R. M. Krauss. 1991. Expression of human apolipoprotein A-I in transgenic mice results in reduced plasma levels of murine apolipoprotein A-I and the appearance of two new high density lipoprotein size subclasses. Proc. Natl. Acad. Sci. USA. 88:434-438.

20. Hayek, T., T. Chajek-Shaul, A. Walsh, L. B. Agellon, P. Moulin, A. R. Tall, and J. L. Breslow. 1992. An interaction between the human cholesteryl ester transfer protein (CETP) and apolipoprotein A-I genes in transgenic mice results in a profound CETP-mediated depression of high density lipoprotein cholesterol levels. J. Clin. Invest. 90:505-510.

21. Walsh, A., N. Azrolan, K. Wang, A. Marcigliano, A. O'Connell, and J. L. Breslow. 1993. Intestinal expression of the human apo A-I gene in transgenic mice is controlled by a DNA region $3^{\prime}$ to the gene in the promoter of the adjacent convergently transcribed apo CIII gene. J. Lipid Res. 34:617-623.

22. Hayek, T., Y. Ito, N. Azrolan, R. B. Verdery, K. Aalto-Setälä, A. Walsh, and J. L. Breslow. 1993. Dietary fat increases HDL levels both by increasing the TR and decreasing the FCR of HDL CE and apo A-I: presentation of a new animal model and mechanistic studies in human apo A-I transgenic and control mice. J. Clin. Invest. 91:1665-1671.

23. Blanche, P. J., E. L. Gong, T. M. Forte, and A. V. Nichols. 1981. Characterization of human high density lipoproteins by gradient gel electrophoresis. Biochim. Biophys. Acta. 665:408-418.

24. Verdery, R. B., D. F. Benham, H. L. Baldwin, A. P. Goldberg, and A. V. Nichols. 1989. Measurement of normative HDL subfraction cholesterol levels by Gaussian summation analysis of gradient gels. J. Lipid Res. 30:1085-1095.

25. Jiao, S., T. G. Cole, R. T. Kitchens, B. Pfleger, and G. Schonfeld. 1990. Genetic heterogeneity of lipoproteins in inbred strains of mice: analysis by gelpermeation chromatography. Metab. Clin. Exp. 39:155-160.

26. Marcel, Y. L. R. McPherson, M. Hogue, H. Czarnecka, Z. Zawadski, P. K. Weech, M. E. Whillock, A. R. Tall, and R. W. Milne. 1990. Distribution and concentration of cholesteryl ester transfer protein in plasma of normolipidemic subjects. J. Clin. Invest. 85:10-17.

27. Bilheimer, D. W., S. Eisenberg, and R. I. Levy. 1972. The metabolism of very low density lipoprotein proteins: preliminary in vitro and in vivo observation. Biochim. Biophys. Acta. 260:212-221.

28. McFarlane, A. S. 1958. Efficient trace labeling of proteins with iodine. Nature (Lond.). 182:53.

29. Stein, Y., Y. Dabah, G. Hollander, G. Halperin, and O. Stein. 1983. Metabolism of HDL-cholesterol ester in the rat studied with a nonhydrolyzable analog cholesteryl linoleyl ether. Biochim. Biophys. Acta. 752:98-105.

30. Matthews, C. M. 1957 . The theory of tracer experiments with ${ }^{131}$ I-labeled plasma proteins. Phys. Med. Biol. 2:36-53.

31. Azrolan, N., and J. L. Breslow. 1990. A solution hybridization RNase protection assay with riboprobes to determine absolute levels of apo B, A-I, and E mRNA in human hepatoma cell lines. J. Lipid Res. 31:1141-1146.

32. Hayek, T., T. Chajek-Shaul, A. Walsh, N. Azrolan, and J. L. Breslow. 1991. Probucol decreases apo A-I transport rate and increases HDL cholesterol ester fractional catabolic rate in control and human apo A-I transgenic mice. Arterioscler. Thromb. 11:1295-1302.
33. Chomczynski, P., and N. Sacchi. 1987. Single-step method of RNA isolation by acid guanidinium thiocyanate-phenol-chloroform. Anal. Biochem. 162:156-159.

34. Mann, C. J., F. T. Yen, A. M. Grant, and B. E. Bihain. 1991. Mechanism of plasma cholesterol ester transfer in hypertriglyceridemia. J. Clin. Invest. 88:2059-2066.

35. Inazu, A., M. L. Brown, C. B. Hesler, L. B. Agellon, J. Koizumi, K. Takata, Y. Maruhama, H. Mabuchi, and A. R. Tall. 1990. Increased high density lipoprotein levels caused by a common cholesteryl-ester transfer protein gene mutation. N. Engl. J. Med. 323:1234-1238.

36. Koizumi, J., A. Inazu, K. Yugi, I. Koizumi, Y. Uno, K. Kajinami, S. Miyamoto, P. Moulin, A. R. Tall, H. Mabuchi, and R. Takeda. 1991. Serum lipoprotein lipid concentration and composition in homozygous and heterozygous patients with cholesteryl ester transfer protein deficiency. Atherosclerosis. 90:189-196.

37. Marotti, K. R., C. K. Castle, R. W. Murray, E. F. Rehberg, H. G. Polites, and G. W. Melchior. 1992. The role of cholesteryl ester transfer protein in primate apolipoprotein A-I metabolism: insights from studies with transgenic mice. Arterioscler. Thromb. 12:736-744.

38. Hulley, S. B., R. H. Rosenman, R. D. Bawol, and R. J. Brand. 1980. Epidemiology as a guide to clinical decisions: the association between triglyceride and coronary heart disease. N. Engl. J. Med. 302:1383-1389.

39. Tall, A. R. 1990. Plasma high density lipoproteins: metabolism and relationship to atherogenesis. J. Clin. Invest. 86:379-384.

40. Azrolan, N., T. Hayek, Y. Ito, R. B. Verdery, T. Chajek-Shaul, A. Walsh, and J. L. Breslow. 1992. A high fat diet increases hepatic production of human apo A-I in transgenic mice. Circulation. 86:I-278.

41. Brinton, E. A., S. Eisenberg, and J. L. Breslow. 1991. Increased apo A-I and apo A-II fractional catabolic rate in patients with low HDL-C levels with or without hypertriglyceridemia. J. Clin. Invest. 87:536-544.

42. Brinton, E. A., S. Eisenberg, and J. L. Breslow. 1989. Elevated HDL-C levels correlate with decreased apo A-I and A-II fractional catabolic rate in women. J. Clin. Invest. 84:262-269.

43. Angelin, B., K. Einarsson, K. Hellström, and B. Leijd. 1978. Bile acid kinetics in relation to endogenous triglyceride metabolism in various types of hypertriglyceridemia. J. Lipid Res. 19:1004-1013.

44. Angelin, B., K. S. Hershon, and J. D. Brunzell. 1987. Bile acid metabolism in hereditary forms of hypertriglyceridemia: evidence for an increased synthesis rate in monogenic familial hypertriglyceridemia. Proc. Natl. Acad. Sci. USA. 84:5434-5438.

45. Avogaro, P., G. Ghiselli, S. Soldan, and G. B. Bon. 1992. Relationship of triglycerides and HDL cholesterol in hypertriglyceridemia. Atherosclerosis. 92:79-86.

46. Witztum, J. L., M. A. Dillingham, W. Glese, J. Dateman, C. Diekman, E. Kammeryer, S. Wiedman, and G. Schonfeld. 1980. Normalization of triglycerides in type IV hyperlipoproteinemia fails to correct low levels of high density lipoprotein cholesterol. N. Engl. J. Med. 303:907-914.

47. Falko, J. M., J. L. Witztum, G. Schonfeld, and J. Bateman. 1979. Dietary treatment of type $\mathrm{V}$ hyperlipidemia fails to normalize low levels of high density lipoprotein cholesterol. Ann. Intern. Med. 91:750-751.

48. Kunsi, T., P. Saarinen, and E. A. Nikkila. 1986. Evidence for the role of hepatic endothelial lipase in the metabolism of plasma high density lipoprotein in men. Atherosclerosis. 36:589-593.

49. Kekki, M. 1980. Lipoprotein-lipase action determining plasma HDL-C level in adult normolipaemics. Atherosclerosis. 37:143-150.

50. Applebaum-Bowden, D., S. M. Haffner, P. W. Wahl, J. J. Hoover, G. R. Warnick, J. J. Albers, and W. R. Hazzard. 1985. Post-heparin plasma triglyceride lipases: relationship with VLDL-triglyceride and $\mathrm{HDL}_{2}$-cholesterol. Arteriosclerosis. 5:273-282. 